\title{
Saint-Petersburg experience of allogeneic hematopoietic stem cell transplantation in patients with acute leukemia and human immunodeficiency virus
}

Boris V. Afanasyev ${ }^{1}$, Marina Popova ${ }^{1}$, Sergey Bondarenko ${ }^{1}$, Ilya Zyuzgin ${ }^{2}$, Elena Babenko ${ }^{1}$, Aleksander Alyanskiy ${ }^{1}$, Susanne Morsch $^{3}$, Jan van Lunzen ${ }^{4}$, Boris Fehse ${ }^{5}$, Axel R. Zander ${ }^{5}$, Ludmila S. Zubarovskaya ${ }^{1}$

${ }^{1}$ Raisa Gorbacheva Memorial Institute of Children Oncology, Hematology and Transplantation, First Pavlov State Medical University of Saint-Petersburg, Russia

${ }^{2}$ Oncology, Hematology and BMT department, Petrov Research Institute of Oncology, Saint-Petersburg, Russia

${ }^{3}$ Stefan Morsch Stiftung, Birkenfeld, Germany

${ }^{4}$ Infectious Diseases Unit, University Medical Center Hamburg-Eppendorf, Hamburg, Germany

${ }^{5} \mathrm{Clinic}$ for Stem Cell Transplantation, University Medical Center Hamburg-Eppendorf, Hamburg, Germany

Raisa Gorbacheva Memorial Institute of Children Oncology, Hematology and Transplantation

First Pavlov State Medical University of Saint-Petersburg, Russia

Marina Popova, MD, Raisa Gorbacheva Memorial Institute of Children Oncology, Hematology and Transplantation, First St. Petersburg State I. Pavlov Medical University,

L. Tolstoy St 6-8, 197022, St. Petersburg, Russia
Phone: +7-812-233-29-25 (office); +7-911-711-39-77 (mobile)

E-mail: marina.popova.spb@gmail.com

\section{Summary}

Introduction of highly active antiretroviral therapy (HAART) in 1996 changed the situation with human immunodeficiency virus (HIV) infection management. HIV-infected patients remain at an increased risk of hematologic malignances for which hematopoietic stem cell transplantation (HSCT) is considered standard therapy. Chemotherapy (CT), including high-dose CT with autologous hematopoietic stem cell transplantation (auto-HSCT) in patients with HIV-associated lymphomas and well-controlled HIV infection on HAART has similar outcomes compared with patients without HIV infection. However, the outcome of HIV-patients after allogeneic hematopoietic stem cells transplantation (allo-HSCT) is unknown with only limited case reports and small series. Most of these patients are potentially curable from hematological malignancies by allo-HSCT. Allo-HSCT from donor with homozygote CCR5 del 32 mutation can cure from the both diseases: HIV and cancer that was demonstrated by the Berlin patient. Prevalence of this mutation is low and this way seems unacceptable in most HIV-pos- itive patients with high-risk hematologic malignancies. Allo-HSCT from donor without CCR5 mutation with ongoing HAART has looked more promising but has failed which was reported as Boston patients. But other aspects including donor type, conditioning regimen, graft-versus-host disease (GvHD) prophylaxis, post-transplant immunoadoptive and new agent therapy in HIV-patients maintain interest to allo-HSCT as a potential cure procedure. It was not reported an allo-HSCT from donor with heterozygote CCR5 del 32 mutation. An application of HAART in post-transplant period can be used not only for HIV control also as a component of GvHD prophylaxis. We report on three HIV-infected patients with high-risk acute leukemia which have undergone an allo-HSCT and donor lymphocyte infusions (DLI) to treat post-allo-HSCT relapse in Saint-Petersburg.

\section{Keywords}

allo-HSCT, HIV, acute leukemia, reduced-intensity conditioning, donor lymphocyte infusion, CCR5 del $32 \mathrm{mu}-$ tation, maraviroc. 


\section{HIV and cancer risk}

Human immunodeficiency virus (HIV) infection represents a growing socio-economic and healthcare problem. Global situation and trends based on World Health Organization data (WHO): since the beginning of the epidemic 35.0 million (33.1-37.2 million) people around the world were living with HIV at the end of 2013 [46]. Patients living with HIV are at high risk of cancer. The introduction of highly active antiretroviral therapy (HAART) in 1996 changed the situation with human immunodeficiency virus (HIV) infection management. HAART is affecting the incidence of several hematological malignancies: the incidence of primary central nervous system lymphoma (PCNSL) has dropped since the introduction of HAART in 1996 and non-Hodgkin lymphoma (NHL) appears to be declining in incidence as well, but to a lesser degree than PCNLS. Between 1990-1995 and 19962002, risk declined for non-Hodgkin lymphoma [(NHL) $\mathrm{n}=3412$; SIR, 53.2 and 22.6, respectively; $\mathrm{p}<0.0001]$. In contrast, the risk of Hodgkin lymphoma increased substantially over the 1990-2002 period $(\mathrm{n}=149$; SIR, 8.1 and 13.6, respectively; $\mathrm{p}=0.003)[10,26]$.

Acute leukemias (AL) are not HIV-indicating diseases. The epidemiology and clinical outcome of acute leukemias in $\mathrm{HIV}$-infected individuals is poorly documented. Rare cases of acute myeloid leukaemia (AML) have been reported during HIV infection and no clear relationship with the characteristic immune deficiency has been established [2, 11, 22, 24, $38,41]$. Like with many other malignancies, the incidence of AML appears to be increased in HIV-infected patients. The estimated risk of AML in 1990 to 1996 among HIV-infected adults was twice that of the general population (standardized incidence ratio 2.05; 95\% confidence interval, $1.17 \pm 3.34$ ) [41]. Acute lymphoblastic leukemia (ALL) is most common in childhood with a peak incidence at 2-5 years of age and rare in adults. An association with HIV infection is not typical and limited to case reports [12, 14, 33, 43]. About 55 cases of AL in HIV-infected patients have been published. Their outcome is very poor, with the median survival of 7 weeks to 7 months $[1,12]$.

Despite introduction of HAART, the HIV-infected patients remain at an increased risk of hematologic malignances for which hematopoietic stem cell transplantation (HSCT) is considered standard therapy [31, 32]. Chemotherapy (CT), including high-dose CT with autologous hematopoietic stem cell transplantation (auto-HSCT) in patients with HIV-associated lymphomas and well-controlled HIV infection on HAART has similar outcomes compared with patients without HIV infection $[9,25]$. However, the outcome of HIV-patients after allogeneic hematopoietic stem cells transplantation (allo-HSCT) is unknown, due to limited number of case reports and small clinical series. In most of these patients, hematological malignancies are potentially curable by allo-HSCT $[13,19,20]$. Wide application of this method is limited by the high risk of fatal infectious complications. Over recent years, some improvements in supportive care, HAART and transplantation technology, allowed to use this therapeutic approach for highly immunocompromised patients.

\section{Donor CCR5 mutation and potential HIV cure}

Interest in finding a potential 'cure' for HIV in anticancer therapy has actually started since the report of an individual who underwent allo-HSCT from a donor with homozygote gene CCR5 delta 32 mutation for acute myeloid leukemia treatment. A potential role of cancer chemotherapy and HSCT treatment is discussed in the context of their role in potential HIV elimination from infected host [20, 29]. Allo-HSCT from a donor with homozygotic CCR5 del $32 \mathrm{mu}-$ tation may cure from the both diseases: HIV and cancer. This opportunity that has been shown in case of the 'Berlin patient' $[3,17,20,47]$. Most experts ascribe the successful allo-HSCT in 'Berlin patient' to a genetic mutation in donor's hematopoietic cells (HSC). The unrelated donor had a del32 mutation of the CCR5 co-receptor, thus causing inability of HIV-1 to infect immune cells [20]. A homozygous state for this mutation, which was found in the population at a frequency of $<1: 1000$, dramatically reduces the risk of HIV-1 entry inside the human lymphocytes. However, prevalence of this mutation is low, and this approach seems unacceptable for the most HIV-positive patients with high-risk hematologic malignancies $[18,34]$.

Allo-HSCT from donors with a wild-type CCR5, along with ongoing HAART, has looked more promising, but it has failed in clinical cases reported as 'Boston patients' [16, 15]. But other aspects, including HSC source, donor type, conditioning regimen, graft-versus-host disease (GvHD) prophylaxis, post-transplant immunoadoptive and novel anti-HIV and anti-cancer agents still maintain interest for allo-HSCT, as a potential cure procedure.

Choice of cord blood (CB) as a source of HSCs can increase the chances of finding an HLA-matched homozygous CCR5 del32 mutation donor for allo-HSCT, and co-transplantation with haplo-HSCs may overcome problems associated with CB HSCT, because the CB transplantation does not require as stringent HLA match between donor and recipient, as bone marrow or peripheral blood HCTs [34]. There is still unclear, which factor in 'Berlin patient' played a crucial role in HIV clearance (donor homozygosity for CCR5 mutation, cytotoxic chemotherapy, graft-associated immunoadoptive effect, or a combined action). There are still no reports on allo-HSCT outcome with donors heterozygous for CCR5 del32 mutation.

Several cytotoxic agents which are routinely used in pre-transplant conditioning regimen, including alkylating agents, such as cyclophosphamide, busulfan, and antimetabolites, have been shown to be effective in depleting HIV-infected cells in vivo or in vitro, and in murine models $[6,27,29,40]$. Introduction of reduced-intensity conditioning regimens (RIC) allows to continue HAART through the transplant procedure. 'Boston patients' demonstrated that allo-HSCT from donor without CCR5 del 32 mutation with ongoing HAART is not sufficient for HIV clearance [15]. But some novel antiretroviral medications could have an additional curative effect post-HSCT. E.g., Maraviroc is a new an- 
tiretroviral agent of entry inhibitor class. Therefore, application of Maraviroc after allo-HSCT could functionally mimic the CCR5 del32 mutation of the HIV target cells. Moreover, it can be used not only for HIV control, but also as a component of GvHD prophylaxis [7, 30, 36].

\section{Immune therapy}

It has been shown that chemotherapy alone cannot eradicate the body reservoirs of HIV. In addition to the cytostatic impact, there is an immunoadoptive effect which can devoid the organism of HIV following allo-HSCT procedure. Moreover, some other anti-cancer post-transplant strategies can be useful in HIV cure. Reduced-intensity conditioning regimens before allo-HSCT represent a promising platform for cancer immunotherapy. This post-transplant strategy includes immunoadoptive therapy with donor lymphocyte infusions (DLI), and new anti-cancer agents that are able for selective killing of tumor cells, as based on their surface expression of tumor-associated antigens targeted by the therapeutic antibodies per se, or linked to cytotoxic compounds (Gentuzimab Ozogamicin, a humanized anti-CD33 monoclonal antibody, Brentuximab Vedotin, a doxorubicin-conjugated anti-envelope antibody). These therapeutic strategies suggest a curative potential for the both diseases, i.e., leukemia and HIV infection [5, 21, 40].

Latently HIV-infected cells comprise the major problem because they are "invisible" to the targeted killing agents. This issue can be resolved by means of activating the infected cells by anti-cancer agents applicable in post-transplant period for targeted chemotherapy, like as GvHD prophylaxis and treatment. E.g., epigenetic manipulation of malignant or virally infected cells with appropriate drugs, such as histone deacetylase inhibitors and proteasome inhibitors, yields results in new cancer therapies (vorinostat for lymphoma, romidepsin for peripheral T-cell lymphoma, and bortezomib for multiple myeloma and mantle cell lymphoma). They could be used to another aim, as HIV-activating drugs in latently infected cells, thus making them more susceptible to apoptosis, or more amenable to direct cytotoxic targeting by other agents $[4,29,35,37]$. Moreover, bortezomib may also have additional anti-HIV effects [28, 29].

Allo-HSCT in patients with hematological malignances and HIV may present a model for the investigations in the field of adoptive therapy with engineered T cells, or stem cell-based treatment against both diseases, i.e., cancer and HIV. Recent progress in stem cell manipulation and in gene engineering of autologous HSCs with vectors carrying the CCR5 mutation has allowed rapid developments in gene therapy for HIV treatment. A number of relevant in vitro and in vivo studies have been published, but the results still are far from definite success $[8,23,39,42,44,45,48$, ]. This strategy looks very promising in the near future.

\section{Clinical cases}

This report includes three cases of the allo-HSCT in patients with an HIV that were performed in Saint-Petersburg, Rus- sia. Baseline values of the patients and transplant characteristics are shown in Table 1.

Patient 1, female, 50 years old was diagnosed with an acute myeloid leukemia in September 2008. First complete remission (CR) was achieved after the fist course of chemotherapy (CT). HIV was diagnosed in March 2009. HIV was transmitted through blood products transfusion (platelets). HAART was not initiated at that time. First early relapse of AML was confirmed in November 2009. No CR after FLAG was registered. Patient had a matched related donor. On March 26th 2010 the allogeneic stem cell transplantation with reduced intensity conditioning regimen (RIC) and standard GVHD prophylaxis (Cyclosporine A + Methotrexate) was performed. Donor: MRD, female (sister), ABO compatibility, CCR5 unknown. Peripheral blood stem cells were used for transplantation (CD34+ cells, $\left.5.8 \times 10^{6}\right)$. No early complications were observed after allo-HSCT. Engraftment was registered on Day +18 . On Day +30 no CR: $80 \%$ donor chimerism and no cytogenetic remission $46, \mathrm{XX}, \operatorname{der}(8) \mathrm{t}(8 ; ?)(\mathrm{q} 10 ;$;) [4]/46,XX[16]. Cyclosporine A was discontinued. DLI with $1 \mathrm{x} 10^{5} \mathrm{CD} 3+/ \mathrm{kg}$ was performed on Day +46 . On Day +70 full donor chimerism and complete remission AML 46,XX were registered. Immunoadoptive therapy was continued: DLI was performed 7 times. HAART was started at the time of immunoadoptive therapy. No GVHD was registered. Viral loads and CD4+ counts for the patient 1 upon treatment are presented in Figure 1.

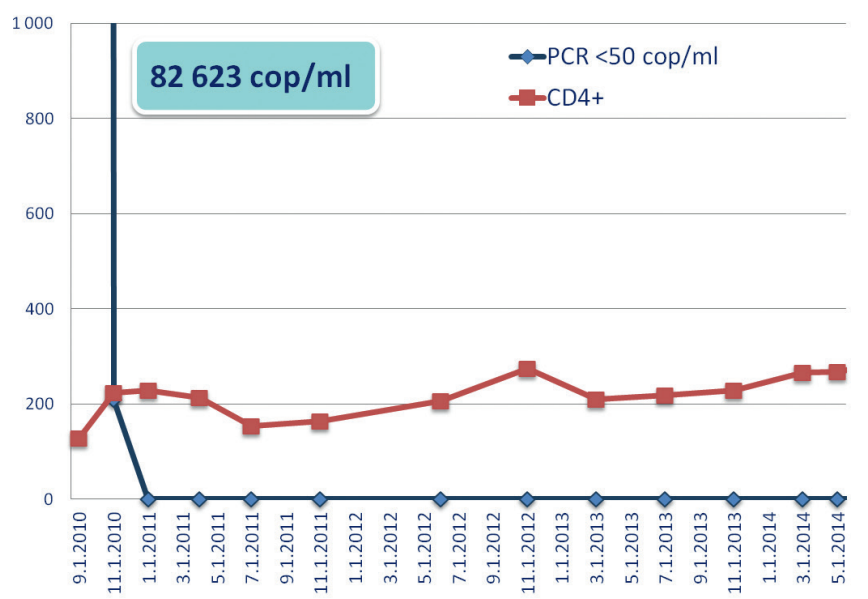

Figure 1. Patient 1: Dynamics of HIV amounts (PCR) and CD4+ counts

At 57 months after allo-HSCT, the patient is in good health and has active lifestyle, in CR AML (full chimerism, 46,XX). There are no signs of HIV-reactivation (PCR $<50$ copies, CD4+ 295 cells; deep virology status performed in Hamburg: Plasma VL RNA copies/ml: 1107, DNA/1 Mio. PBMC: 2265, Integrated HIV DNA/PCR: 17.670, HIVAb/p24Ag 4th generation: pos./neg.). She is still on HAART: Prezista $800+$ Ritonavir $100+$ Lamivudine 300 .

Patient 2, female, 29 years old was diagnosed with an acute lymphoblastic leukemia in 1993 (at the age of 10). First CR was achieved after the first course of chemotherapy. A HIV/ hepatitis C co-infection was diagnosed in 2005. HIV was 
transmitted from the patient's husband. HAART was started in 2009. First late relapse of ALL was confirmed in October 2011. Second CR MRD (+) was achieved after second course Hyper-CVAD / MxA treatment in December 2011. Full chemotherapy program (8 cycles) of Hyper-CVAD / MxA was completed in May 2012. Patient had no related matched donors. A search for the unrelated donor was initiated in February 2012. By the time of HSCT, the patient has achieved a second remission of ALL, MRD (+), HIV status was satisfactory: PCR $<50$ copies, CD4+ 108 cells on HAART. On 19 July 2012, an allogeneic stem cell transplantation was performed, with reduced intensity conditioning (RIC) regimen and standard GVHD prophylaxis, including ATG + tacrolimus and MMF. Donor: MUD, female, ABO-compatible, CCR5, wt/wt. Source of HSC: PBSC (CD34+ $\left.9.1 \times 10^{6}\right)$. No severe infectious complications were registered in pre-engraftment phase. Due to severe tacrolimus toxicity, the GVHD prophylaxis was modified, by switching from tacrolimus to corticosteroids. Engraftment was registered on Day +12 . On Day +23 , CMV reactivation with severe CMV disease of gut was diagnosed, as shown by biopsy. The patient died on Day +41 from generalized gancyclovir-resistant CMV disease affecting gut, liver, and kidneys.

Patient 3, female, 26 years old was diagnosed with HIV, and HAART was immediately administered in April 2012. HIV was transmitted from the patient's husband. Acute leukemia of mixed phenotype was diagnosed in May 2012. First CR with MRD (+) was achieved only after at the $3^{\text {rd }}$ course of chemotherapy. The patient had no matched related donors. A search for unrelated donor was initiated in December 2012. At the moment of HSCT, the ALL disease was in its first remission, MRD (+); HIV status was satisfactory: PCR $<50$ copies, CD4+ 117 cells on HAART. On the April 1, 2013, allogeneic stem cell transplantation with a RIC regimen and standard GVHD prophylaxis (ATG+cyclosporine A+MMF), including Maraviroc, was performed.

Maraviroc is an antiretroviral agent belonging to the CCR5 receptor antagonists, as well as entry inhibitors, it is used for treatment of HIV infection. It also appears to reduce graftversus-host disease in patients treated with allogeneic bone marrow transplantation for leukemia, in a phase $1 / 2$ study [36].

We have tested the recipient and donor for a CCR5 gene mutation. The recipient (patient 3) had no CCR5 delta32 mutation (wild type/wild type). The donor harbored a single CCR5 delta32 allele (a heterozygotic state). A male, HLAmatched, ABO-incompatible, unrelated donor was used for HST. Peripheral blood stem cells were used as a source of HSCs (CD34+ cells, 6,5 x 106). No relevant complications in pre-engraftment phase were registered. Engraftment and acute GVHD of the skin grade 2-3 were registered since Day +12 . GVHD was treated by a high dose of CsA (control serum level) + prolonged MMF and Maraviroc + topic steroids. On the Day +60 , no signs of GVHD were reported. Immunosupressive therapy was discontinued on the Day +100 due to the MRD positivity registered by flow cytometry. Local light skin chronic GVHD was observed for two months, and CR with MRD (-) was achieved. Viral loads and CD4+ counts in the patient 3 during treatment are presented in Fig. 2.

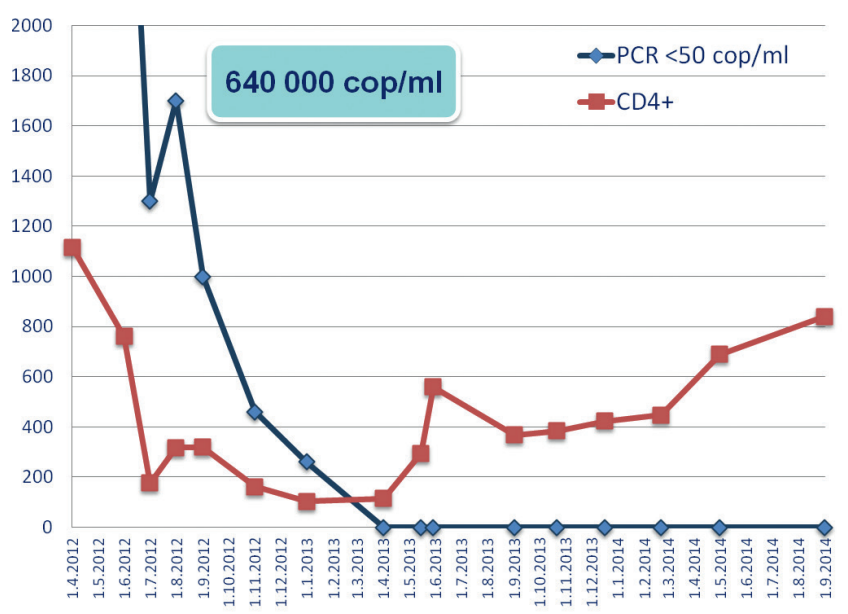

Figure 2. Patient 3: Dynamics of HIV amounts (PCR) and CD4+ counts

Currently, at 22 months after allo-HSCT, the patient is in a good health and has an active lifestyle, CR of acute leukemia (full chimerism, MRD(-)), with no signs of HIV-reactivation (PCR $<50$ copies, CD4+ 828 cells; deep virology status in Hamburg: Plasma VL RNA copies/ml: 43, DNA/1 Mio. PBMC: 71, Integrated HIV DNA/PCR: 517, HIVAb/p24Ag 4th generation: pos./neg.). She is still on HAART: Abacavir 600 + Lamivudine $300+$ Raltegravir 800. An important fact is that the patient's sample contained the CCR5-wildtype-allele and the CCR5 del 32 mutation = donor's heterozygote type and was converted to heterozygote CCR5 del $32 \mathrm{mu}-$ tation.

In conclusion, allo-HSCT with RIC is an effective and feasible therapeutic modality for high-grade hematological malignancies in patients with HIV. There were no severe toxicity and drug-drug interactions between HAART, conditioning regimen, and immunosuppressive drugs. HAART and immunosuppressive agents can be safely administered after allo-HSCT. Engraftment and full donor chimaerism were achieved at term as in the general population allo-HSCT recipients. Relapse of acute leukemia could be successful and safety treated with immunoadoptive therapy (DLI) after allo-HSCT. There were no specific infections or other particular complication in HIV positive pts after allo-HSCT. We suggest that patient 3 may be "near to functional cure". Allo-HSCT ongoing with HAART is the same effective and safety strategy for the treatment high-risk hematologic malignancies in HIV population.

\section{Acknowledgements}

Staff of CIC 725, Raisa Gorbacheva Memorial Institute of Children Oncology, Hematology and Transplantation, First Pavlov State Medical University of Saint-Petersburg, Russia and International Registry Stefan Morsch Stiftung, Birkenfeld, Germany.

No conflict of interest is reported. 


\begin{tabular}{|c|c|c|c|}
\hline Characteristics & Case 1 & Case 2 & Case3 \\
\hline $\begin{array}{l}\text { Demographic } \\
\text { Age }\end{array}$ & 50 & 29 & 26 \\
\hline Diagnosis & AML & ALL & AL, mixed phenotype \\
\hline Status & CR2 & CR2 & CR1 \\
\hline $\begin{array}{l}\text { HIV status at Tx } \\
\text { CD4+ }\end{array}$ & 500 cells/ml & 380 cells/ml & 114 cells/ml \\
\hline HIV-VL & 700 copies/ml & $<50$ copies/ml & $<50$ copies/ml \\
\hline CART & No & Yes & Yes \\
\hline $\begin{array}{l}\text { Transplant } \\
\text { Donor type } \\
\text { CCR5 del32 }\end{array}$ & $\begin{array}{l}\text { Sibling matched } \\
\text { NA }\end{array}$ & $\begin{array}{l}\text { MUD (12/12) } \\
\text { wt/wt }\end{array}$ & $\begin{array}{l}\text { MUD (12/12) } \\
\text { del 32/wt; heterozygote }\end{array}$ \\
\hline Conditioning & RIC (Flu150+Bu8) & RIC (Flu150+Mel140) & RIC (Flu150+Bu8) \\
\hline GvHD proph & CsA & ATG, MMF, steroids & ATG, CsA, MMF, maraviroc \\
\hline $\begin{array}{l}\text { Engraftment } \\
\text { Neutrophil }\end{array}$ & $+18 d$ & $+12 d$ & $+18 d$ \\
\hline Platelet & $+19 d$ & $+14 d$ & $+18 d$ \\
\hline Full donor chimaerism & $+25 d$ & $+20 d$ & $+20 d$ \\
\hline $\begin{array}{l}\text { GvHD } \\
\quad \text { Acute, grade }\end{array}$ & No & No & II \\
\hline Chronic & No & No & No \\
\hline LFU & 57 months & 41 days & 22 months \\
\hline Status at LFU & Alive & Dead & Alive \\
\hline $\begin{array}{l}\text { HIV status at LFU } \\
\text { CD4+ }\end{array}$ & 800 cells/ml & NA & 480 cells/ml \\
\hline HIV-VL & $<50$ copies $/ \mathrm{ml}$ & NA & $<50$ copies $/ \mathrm{ml}$ \\
\hline CART & Continues & NA & Continues \\
\hline
\end{tabular}

Table 1. Baseline patients and transplants characteristics

\section{References}

1. Aboulafia DM, Meneses M, Ginsberg S et al. Acute myeloid leukemia in patients infected with HIV-1. AIDS 2002; 16(6):865-76.

2. Al-Bahar S, Pandita R, Dhabhar BN, Al-Bahar E. Human immunodeficiency virus (HIV) infection associated with acute myeloblastic leukaemia in a low HIV prevalence area. Acta Haematol 1994; 91: 52-53.

3. Allers K, Hütter G, Hofmann J et al. Evidence for the cure of HIV infection by CCR5 delta 32 / delta32 stem cell transplantation. Blood 2011; 117(10): 2791-9.

4. Archin NM, Libesty AL, Kashuba AD et al. Administration of vorinostat disrupts HIV-1 latency in patients on antiretroviral therapy. Nature 2012; 482: 482-5.
5. Berger EA. Targeted cytotoxic therapy: adapting a rapidly progressing anti-cancer paradign for depleting HIV infected cell reservoirs. Curr Opin HIV/AIDS 2011; 6: 80-5.

6. Borvak J, Chou CS, Van Dyke G et al. The use of cyclosporine, FK506, and SDZ NIM811 to prevent CD25-quiescent peripheral blood mononuclear cells from producing HIV. J Infect Dis 1996; 174: 850-3.

7. Choi SW, Reddy P. Current and emerging strategies for the prevention of graft versus host disease. Nat Rev Clin Oncol 2014; 11(9): 536-47.

8. Didigu CA, Wilen CB, Wang J et al. Simultaneous zinc-finger nuclease editing of the HIV coreceptors CCR5 and CXCR4 protects CD4+ T cells from HIV-1 infection. Blood 2014; 123(1): 61-9. 
9. Diez-Martin JL, Balsalobre P, Re A et al. Comparable survival between HIV+ and HIV-non-Hodgkin and Hodgkin lymphoma patients undergoing autologous peripheral blood stem cell transplantation. Blood 2009; 113(23): 6011-14.

10. Engels EA, Pfeiffer RM, Goedert JJ et al. Trends in cancer risk among people with AIDS in the United States 1980 2002. AIDS 2006; 20(12): 1645-54.

11. Farber CM, Ferehans W, Capel P et al. Chemotherapy of acute myeloblastic leukaemia in an HIV carrier. Eur J Haematol 1993; 51: 180.

12. Geriniere L, Bastion Y, Dumontet C et al. Heterogeneneity of acute lymphoblastic leukaemia in HIV-seropositive patients. Ann Oncol 1994; 5(5): 437-40.

13. Gupta V, Tomblyn M, Pedersen TL et al. Allogeneic hematopoietic cell transplantation in human immunodeficiency virus-positive patients with hematologic disorders: a report from the Center for International Blood and Marrow Transplant Research. Biol Blood Marrow Transplantion 2009; 15: 864-71.

14. Hamilton J, McBride M, Kettle P. Acute B cell lymphoblastic leukaemia and human immunodeficiency virus infection (HIV). Ulster Med J 2002; 71(1): 72-5.

15. Henrich T, Hanhauser E, Marty FM et al. Antiretroviral-free HIV-1 remission and viral rebound after allogeneic stem cell transplantation: report of 2 cases. Ann Intern Med 2014; 161(5): 319-27.

16. Henrich T, Hu Z, Li JZ et al. Long-term reduction in peripheral blood HIV type 1 reservoirs following reduced-intensity conditioning allogeneic stem cell transplantation. J Infect Dis 2013; 207(11):1694-702.

17. Hütter G, Ganepola S. Eradication of HIV by transplantation of CCR5-deficient hematopoietic stem cells. The Scientific World J 2011; 11: 1068-76.

18. Hütter G, Thielb E. Allogeneic transplantation of CCR5-deficient progenitor cells in a patient with HIV infection: an update after 3 years and the search for patient no. 2 . AIDS 2011;25: 273-75.

19. Hütter G, Zaia JA. Allogeneic haematopoietic stem cell transplantation in patients with human immunodeficiency virus: the experiences of more than 25 years. Clin Exp Immunol 2011; 163; 284-95.

20. Hütter G, Nowak D, Mossner M et al. Long-term control of HIV by CCR5 delta32/ delta32 stem-cell transplantation. N Engl J Med 2009; 360: 692-8.

21. Johansson S, Goldenberg DM, Griffiths GL et al. Elimination of HIV-1 infection by treatment with a doxorubicin-conjugated antienvelope antibody. AIDS 2006; 20: 1911-5.

22. Kane D, Keating S, McCann S, Mulcahy F. The management of acute myeloid leukaemia (AML) in human immunodeficiency virus (HIV) infection: a case report and review. Int J STD and AIDS, 1997; 8: 272-4.

23. Kiem HP, Jerome KR, Deeks SG et al. Hematopoietic-stem-cell-based gene therapy for HIV disease. Stem Cell 2012; 10: 137-47.
24. King JAC, Nye DM, O'Connor MB et al. Acute myelogenous leukemia (FAB AMLM1) in the setting of HIV infection and G-CSF therapy: a case report and review of the literature. Ann Hematol 1998; 77: 69-73.

25. Krishnan A, Palmer JM, Zaia JA et al. HIV status does not affect the outcome of autologous stem cell transplantation (ASCT) for non-Hodgkin lymphoma (NHL). Biol Blood Marrow Transplant 2010; 16(9): 1302-8.

26. Launay O, Guillevin L. Epidemiology of HIV-associated malignancies. Bull Cancer 2003; 90(5); 387-92.

27. Little RF, Pittaluga S, Grant N et al. Highly effective treatment of AIDS-related lymphoma with dose-adjusted EPOCH: impact of antiretroviral therapy suspension and tumor biology. Blood. 2003; 101: 4653-9.

28. Liu B, Yu X, Luo K et al. Influence of primate lentiviral Vif and proteasome inhibitors on human immunodeficiency virus type 1 virion packaging of APOBEC3G. J Virol 2004; 78: $2072-81$.

29. Mitsuyasu R. Curing HIV: lessons from cancer therapy. Curr Opin HIV AIDS 2013; 8(3): 224-9.

30. Nakamura R, Forman SJ. Reduced intensity conditioning for allogeneic hematopoietic cell transplantation: considerations for evidence-based GVHD prophylaxis Expert Rev Hematol 2014; 7(3), :407-21.

31. Passweg J, Baldomero H, Bader P et al. Hematopoietic SCT in Europe: recent trends in the use of alternative donors showing more haploidentical donors but fewer cord blood transplants. Bone Marrow Transplantation 2015; Suppl 50: 476-82.

32. Passweg J, Baldomero H, Peters C et al. Hematopoietic SCT in Europe: data and trends in 2012 with special consideration of pediatric transplantation. Bone Marrow Transplantation 2014 ; Suppl 49: 744-50.

33. Pees HW, Radtke H, Schwamborn J et al. The BFM-protocol for HIV-negative Burkitt's lymphomas and L3 ALL in adult patients: a high chance for a cure. Ann Hematol 1992; 65(5): 201-5.

34. Petz L. Cord Blood Transplantation for Cure of HIV Infections. Stem Cells Transl Med 2013; 2: 635-7.

35. Piekarz RL, Frye R, Prince HM et al. Phase 2 trial of romidepsin in patients with peripheral T-cell lymphoma. Blood 2011; 117: 5827-34.

36. Reshef R, Luger SM, Hexner EO et al. Blockade of lymphocyte chemotaxis in visceral graft-versus-host disease. $\mathrm{N}$ Engl J Med 2012; 367(2): 135-45.

37. Reuse S, Calao M, Kabeya K et al. Synergistic activation of HIV-1 expression by deacetylase inhibitors and prostratin: implications for treatment of latent infection. PLoS One 2009;4:e6903.

38. Rivers JK, Laubenstein LJ, Postel AH. Acute monocytic leukaemia in an HIV-seropositive man. Clin Exp Dermatol 1992; 17: 203-5. 
39. Shimizu S, Ringpis GE, Marsden MD et al. RNAi-mediated CCR5 knockdown provides HIV-1 resistance to memory T cells in humanized BLT mice. Mol Ther Nucl Acids 2015 Feb; 4(2): e227.

40. Simard C, Jolicoueur P. The effect of antineoplastic drugs on murine acquired immunodeficiency syndrome. Science 1991; 252:305-8.

41. Sutton L, GueAnel P, Tanguy ML et al. Acute myeloid leukaemia in human immunodeficiency virus infected adults: epidemiology, treatment feasibility and outcome. Brit J Haematol 2001; 112: 900-8.

42. Tebas P, Stein D, Tang WW et al. Gene editing of CCR5 in autologous CD4 T cells of persons infected with HIV. N Engl J Med 2014; 370: 901-10.

43. Turner ML, Watson HG, Russell L et al. An HIV positive haemophiliac with acute lymphoblastic leukaemia suc- cessfully treated with intensive chemotherapy and syngeneic bone marrow transplantation. Bone Marrow Transplant 1992; 9(5): 387-9.

44. van Lunzen J, Fehse B, Hauber J. Gene Therapy Strategies: Can We Eradicate HIV? Curr HIV/AIDS 2011; Rep 8: 78-84.

45. van Lunzen J, Glaunsinger T, Stahmer I et al. Transfer of autologous gene-modified T cells in HIV-infected patients with advanced immunodeficiency and drug-resistant virus Mol Ther 2007; 15: 1024-33.

46. World Health Organization http://www.who.int/hiv/data 47. Yukl SA, Boritz E, Busch M et al. Challenges in detecting HIV persistence during potentially curative interventions: A study of the Berlin patient. PLOS Pathogens 2013; 9 (5): e1003347. doi:10.1371/journal.ppat.1003347.

48. Zhen A, Kitchen S. Stem-cell-based gene therapy for HIV infection. Viruses 2014; 6: 1-12; doi:10.3390/v6010001.

\section{Аллогенная трансплантация гемопоэтических стволовых клеток у пациентов с острым лейкозом и ВИЧ-инфекцией, опыт Санкт-Петербурга}

Борис В. Афанасьев, Марина Попова, Сергей Бондаренко, Илья Зюзгин, Елена Бабенко, Александр Алянский, Сюзанна Морш, Ян ван Лунзен, Борис Фезе, Аксель Цандер, Людмила С. Зубаровская

\section{Резюме}

Внедрение высокоактивной антиретровирусной терапии (ВААРТ) в 1996 году изменило ситуацию с лечением ВИЧ-инфекции. Несмотря на широкое применение ВААРТ, пациенты с ВИЧ по-прежнему относятся к группе высокого риска развития злокачественных опухолей кроветворной и лимфатической ткани. Трансплантация гемопоэтических стволовых клеток (ТГСК) является стандартным лечением для большинства этих опухолей. Противоопухолевая химиотерапия (ПХТ), включая высокодозную ПХТ с аутологичной ТГСК, так же эффективна как у пациентов без ВИЧ при применении ВААРТ. В то время как результаты аллогенной ТГСК (алло-ТГСК) неизвестны, публикации ограничены отдельными случаями или небольшими группами пациентов. Часть пациентов потенциально могут быть излечены от двух заболеваний при проведении алло-ТГСК от донора с гомозиготной мутацией гена CCR5 del 32: злокачественная опухоль и ВИЧ, что было продемонстрировано у «Берлинского пациента». Встречаемость мутации гена CCR5 del 32 в популяции невысока, такой способ лечения малоперспективен для большинства пациентов с ВИЧ и онкогематологическим заболеванием из-за низкой вероятности найти HLAсовместимого донора с гомозиготной мутацией гена CCR5 del 32. Алло-ТГСК от донора без мутации гена CCR5 del 32 на фоне ВАAРТ выглядело более перспективным, но опыт «Бостонских пациентов» продемонстрировал неэффективность такого подхода. При этом, другие аспекты, включающие тип донора, режим кондиционирования и профилактики РТПХ, посттрансплантационную иммуноадоптивную терапию, поддерживают интерес к алло-ТГСК у пациентов с ВИЧ, как потенциального метода излечения от двух заболеваний. Нет опубликованных данных об алло-ТГСК от донора с гетерозиготной мутацией гена CCR5 del 32, а ВАAPT в посттрансплантационном периоде может быть использована в качестве компонента профилактики РТПХ. Мы представляем собственный опыт алло-ТГСК у пациентов с острыми лейкозами и ВИЧ-инфекцией, выполненные в Санкт-Петербурге.

\section{Ключевые слова}

Алло-ТГСК, ВИЧ, острый лейкоз, кондиционирование сниженной интенсивности, инфузии донорских лимфоцитов, мутации CCR5 del 32, маравирок. 